\title{
Residential self-selection in travel behavior: Towards an integration into mobility biographies
}

\author{
Joachim Scheiner ${ }^{\text {a }}$ \\ Technische Universität Dortmund
}

\begin{abstract}
The debate on residential self-selection (RSS) in the travel field seeks to answer the question of whether and to what extent spatial differences in traveling may be explained in spatial terms or to what extent, rather, they are explained by the unequal spatial distribution of people's social and personal characteristics, particularly their neighborhood and travel preferences. Arguing primarily from a European-specifically, German-perspective, this paper makes a case for integrating the RSS-travel link into the mobility biographies approach that has emerged over the past decade. This approach addresses travel behavior as being embedded in other "spheres" of an individual's life course, most notably the household and family biographies, the employment biography, and the residential biography. This paper argues that stability and change in travel behavior must be considered not only in concert with residential location choice, but also in the wider context of life course, in which residential choices themselves are embedded. Some unresolved issues in the RSS-travel debate that seem to be of key importance for the current debate are discussed, including various aspects of residential location choice, the role of preferences, and implications for spatial planning and transport planning. The benefits of taking a biographical perspective are also pointed out.
\end{abstract}

Keywords: residential self-selection, travel behavior, mobility biography, residential location choice

\section{$1 \quad$ Background}

\subsection{The context of the residential self-selection debate in travel studies}

The unequal spatial distribution of various population groups has been a topic of scientific inquiry ever since the pioneering work of the Chicago School of Sociology (Park, McKenzie, and Burgess 1925). The focus was then on population groups defined by their social status or race. Since about 1980, lifestyles and consumer preferences for housing, neighborhood, and urban amenities have been considered simultaneously with, or have even replaced, social status in segregation and gentrification studies.

In travel behavior studies, socio-demographic differences have also played a key role since at least the 1960s and, more prominently, since 1970s time geography (Carlstein, Parkes, and Thrift 1978) and the emergence of activity-based transport modeling (Jones et al. 1983). At that time, there was also intensive research on the role of attitudes in travel behavior (Tardiff 1977), including the effects of travel preferences-e.g., concerning public transport (Pickup and Town 1983) or commute modes (Horowitz 1986) — on residential location choice.

However, it was only in the 1990s that notable debate on the endogeneity of residential choice began to emerge in travel studies, systematically developing the questions raised by the existence, strength, and implications of residential self-selection (RSS) . In essence, this debate seeks to answer the question of which implications the unequal spatial distribution of individuals with different social and personal characteristics has for understanding travel behavior or the availability of mobility tools. The focus is on that particular type of unequal spatial distribution that is motivated by the households themselves, particularly by their preferences toward residence, neighborhood, and residential location (in brief,

a joachim.scheiner@tu-dortmund.de

Copyright 2014 Joachim Scheiner.

Licensed under the Creative Commons Attribution - NonCommercial License 3.0. 
neighborhood preferences), and traveling (travel preferences). The specific focus of this debate is on the question of whether and to what extent spatial differences in traveling may be explained in spatial terms, i.e., as caused by attributes of the spatial context in which people live or to what extent they are rather explained by the unequal spatial distribution of their social and personal characteristics, i.e., by sociospatial/attitudinal segregation.

Hence, this debate does not originate from a discussion of social or psychological differences in travel behavior, although it has a strong focus on these issues, but from the land-use transport debate. In this debate, the issue of RSS marks an important step toward the methodologically and theoretically more rigorous investigation of the link between land use and travel.

From the beginning the RSS-travel debate was strongly linked to the lifestyle debate in the United States (Kitamura, Mokhtarian, and Laidet 1997; Bagley and Mokhtarian 2002) as well as in Europe (Scheiner and Holz-Rau 2007; Bohte 2010; Scheiner 2010; Naess 2013). This is hardly surprising, as lifestyles reflect preferences to a large extent, even if they may also include behavioral aspects such as leisure or consumer behavior (see Scheiner and Holz-Rau 2007; Bohte 2010; Scheiner 2010 for discussion). In Germany, preferences toward travel modes have even been discussed using the term "mobility styles" (Götz, Jahn, and Schultz 1997; Ohnmacht, Götz, and Schad 2009).

\subsection{The perspective taken in this paper}

This paper does not intend to provide a comprehensive review of empirical knowledge on RSS (see Cao, Mokhtarian, and Handy 2009 for an excellent overview) or on methodologies used (Mokhtarian and Cao 2008; Bhat and Guo 2007; Bohte, Maat, and van Wee 2009). Rather, I discuss some key issues of the RSS-travel relationship, deriving suggestions for further research, and call for an integration of the RSS-travel link into the wider context of mobility biographies. This would serve to improve understanding of stability and change in mobility over people's life courses, and the role spatial mobility plays for other spheres of their lives, such as their residential, employment, and household/family biographies. The RSS-travel link may be understood as a specific sphere in these intertwined "partial biographies" that focuses on the link between residential choice and travel choices, but without taking other spheres systematically into account. Hence, the main contribution of this paper is in suggesting a perspective for widening the scope of research on the RSS-travel link.

The next section briefly summarizes key well-established findings from RSS-travel studies. Section 3 discusses key issues for further research and Section 4 makes the case for mobility biographies as a perspective for framing the RSS-travel link.

I argue primarily from a European, specifically German, perspective. The RSS-travel debate is somewhat younger and less developed in Europe than in the United States. The implications of addressing preferences in residential location choice for travel studies were first touched upon in Germany in the 1990s (Holz-Rau 1997; Holz-Rau et al. 1999; Scheiner 1998), and were not empirically addressed at that time. The first German studies that included travel preferences and/or lifestyles were conducted at the end of the 1990s (Götz, Jahn, and Schultz 1997; Lanzendorf 2001; Scheiner 2000). The first empirical travel behavior study addressing neighborhood and accessibility preferences in Germany was the

\footnotetext{
${ }^{1}$ Some authors use the term "residential sorting" instead of residential self-selection. I prefer the latter, as residential sorting does not necessarily imply that residents sort themselves into certain locations. Rather, they may just as well "be sorted" by market conditions or even political forces. In these cases the sorting process would not reflect their own preferences, but external circumstances such as political will. Residential sorting may be an appropriate term nonetheless, particularly when a study refers to unequal spatial distribution based on socio-demographics alone, as these reflect constraints to a large extent.

${ }^{2}$ Variables of interest may include household or individual car ownership, car availability. or PT season ticket ownership, all of which are not travel behavior variables, but instead reflect pre-decisions on intended travel behaviour (specifically on mode choice). The term "travel demand" could be used to capture both the availability of such mobility tools and travel behavior likewise, but travel demand is broadly used for aggregate rather than individual demand. I therefore deliberately use the term "travel behavior" here to include the availability or ownership of mobility tools.
} 
Intermobil Region Dresden project in 2000 (Bauer, Holz-Rau, and Scheiner 2005). In the StadtLeben project (Beckmann et al. 2006) and its follow-up project (Scheiner 2009) the idea of RSS operating in concert with lifestyles was systematically developed and applied in a German context. I was involved in these three projects, and this paper draws on my own work to a considerable extent, as there is relatively little research on the RSS-travel link in Germany.

Is there a need for continent- or nation-specific perspectives? Generally one may assume that the more mixed land-use structures within a region are, the more options people have for destination choice. Similarly, the more varied transport systems are, the more options people have for mode choice. European cities typically offer more options in terms of traveling than US cities. Hence, moving house may alter travel options and more readily allow the adaptation of place of residence to preferences than in US cities. These considerations favor the idea of relatively strong self-selection manifesting in European cities, based on the characteristic mixed land-use and well-developed public transport.

There is some evidence from a comparative analysis of the United States and the United Kingdom (Aditjandra, Mulley, and Nelson 2009). In this study, travel preferences turned out to be the strongest predictor of vehicle miles driven in the US, while in the UK socioeconomics were more important. Land use also appeared to play a bigger role for vehicle miles driven in the UK. The authors conclude that RSS "may not be as big an issue in the UK, as compared to the US, because alternatives are more available for those who have preferences - both pro-public transport and pro-car" (Aditjandra, Mulley, and Nelson 2009, 31). As outlined above, I favor the contrary hypothesis of stronger (or more frequent) RSS in regions with more options. This notion is supported by studies that find preferences play a larger role in urban than in suburban contexts (Schwanen and Mokhtarian 2005; Aditjandra, Mulley, and Nelson 2013), although others (Van Acker, Derudder, and Witlox 2011) suggest it is the other way round.

Another issue that raises doubt about the direct transferability of findings from the United States to Europe is the countryside. The RSS-travel debate has so far been almost exclusively devoted to urban regions. European rural areas are characterized by considerable internal variation. For example, rural areas in Germany include small towns with well-developed local bus and regional train systems and a high level of small-scale, nonmotorized access to work, education, shopping, and services, while more remote, scattered villages may provide only basic services — if any at all—and have little connection to urban regions.

\section{$2 \quad$ Key findings from RSS-travel studies}

From the several dozen RSS-travel studies conducted in the last 15 years or so one may derive four relatively consistent key findings.

1) Neighborhood and travel preferences play a role in travel behavior. Mostly they tend to reduce the effects of other variables, including land use and life situations ${ }^{3}$ (review in Cao, Mokhtarian, and Handy 2009). This finding suggests that both life situations and land use to some extent capture preferences as long as preferences are not explicitly controlled for. However, the consideration of preferences may also increase the effects of land use on travel when there are many mismatched residents (Schwanen and Mokhtarian 2005) — e.g., when those with a strong preference for public transport are forced to live in car-oriented neighborhoods because of a lack of (available housing in) neighborhoods with good public transport service (Chatman 2009).

2) Land use has significant effects on travel behavior, irrespective of the methodology used to consider RSS (again, see Cao, Mokhtarian, and Handy 2009), but depending on the behavioral vari-

\footnotetext{
${ }^{3}$ I use the term "life situation" to capture socio-demographics. Socio-demographics is just a formal term while its societal content may be captured by the term life situation, which has typically been theorized as reflecting social roles, resources, and constraints.
} 
ables under study. While land-use effects on activity participation and trip frequencies are modest, effects on trip distances and mode choice are more pronounced (for Denmark, see Naess 2006; for Germany, see Vance and Hedel 2007). Longitudinal analyses typically suggest adaptations in travel behavior to spatial context after residential relocation (see Scheiner and Holz-Rau 2013 for the use of different modes in Cologne), even when preferences are controlled for (e.g., Handy, Cao, and Mokhtarian 2005 for the US; Aditjandra, Cao, and Mulley 2012 for the UK. Note that in all studies I am aware of, preferences are measured—if at all—subsequent to behavior change).

3) Objective life situation typically explains more variance in travel behavior than preferences (Scheiner and Holz-Rau 2007; Scheiner 2010; Bohte 2010, 81-109). This is consistent with expectations, as preferences can only be realized if allowed by the more basic prerequisites of resources, social roles, or time budgets.

4) As long as car availability is not the outcome variable (as in Bhat and Guo 2007 and Cao, Mokhtarian, and Handy 2007), it is an intervening variable of central importance (Scheiner 2010; Van Acker and Witlox 2010). In contrast to ownership of bicycles, cars are major investments made only if there is a strong intention to actually use the car. This investment is thus an important pre-decision for travel behavior.

\section{$3 \quad$ Key issues for further research}

The following basic components can be identified in RSS-travel studies:

- Individual or household life situation (possibly complemented by lifestyle and/or preferences in a wider sense beyond travel, residence, and neighborhood).

- Individual or household preferences ${ }^{4}$ toward travel and spatial context at the residence (accessibility, location) plus, possibly, the environment and other issues.

- Actual spatial context at the residence (neighborhood, location, options for traveling, accessibility).

- Ownership or availability of mobility tools (particularly cars).

- Travel behavior.

The first two bullet points are typically considered to represent the potential sources for RSS (Mokhtarian and Cao 2008). One may add mobility tool ownership/availability. Two key issues, which are elaborated upon in the following subsections, appear to be central to the further development of the RSS-travel field:

- A variety of questions concerning residential location choices.

- The role of preferences.

The reference to mobility biographies is tackled briefly at the end of each subsection. Another question refers to the more practical implications of the RSS-travel debate: What are the implications of this

\footnotetext{
${ }^{4}$ Attitudes are a person's evaluations of objects, including stimuli, behaviors, or concepts (Herkner 1991, 180-273). Preferences are a particular type of such evaluations (called type 1-attitude here). Preferences are dispositions toward an alternative, typically conceived of as shaping individual or household decisions and actions (Mas-Colell, Whinston, and Green 1995). However, such evaluations also include levels of (dis)satisfaction, by which existing or perceived characteristics of an object are assessed (type 2). A person mismatched in her neighborhood may have a strong preference (positive type 1-attitude) towards PT, but may be dissatisfied with PT as it is (negative type 2-attitude). As the idea of RSS is mainly based on type 1-attitudes, I use the term preference here, wherever possible.
} 
debate for urban planning and transport planning?

\subsection{Residential location choice}

Residential location choice is an overwhelmingly large research field involving a wide range of disciplines, including sociology, psychology, economics, geography, planning studies, and others. The fundamentals of residential location choice, its impact factors, and relevant circumstances are generally well recognized (see for Germany Frick 1996; Kalter 1997; and for the Netherlands, Dieleman and Mulder 2002). They include, on the one hand, the regional housing supply, and on the other hand, the resources, needs, and preferences of residence-seeking households.

For the RSS-travel field, some pertinent questions are important in this respect:

1) A notable shortcoming in this wider field (beyond transport studies) is the lack of consideration given to transport variables. This refers to mobility tools as well as to transport-related preferences. For instance, the choices of those who do not have a car tend to be limited to locations with good PT access (Van Wee, Holwerda, and Van Baren 2002; for Germany, see Hesse and Scheiner 2009). The idea that access and mobility have little relevance for residential location choice in societies with extremely high levels of access and mobility (for Germany, see Grund 1997) is not convincing. Chatman (2009) reports that 53 percent of all respondents from his California data sought travel access of some kind when looking for a neighborhood to locate in. About 30 percent of intra-regional movers and 17 percent of intra-urban movers in Cologne even reported that mobility or access problems (such as lack of facilities, lack of PT service, lack of road access) were reasons for their relocation (Beckmann et al. 2006, 180). Indeed, in a society of universal access and mobility some respondents may find it difficult to explicitly state the relevance of access and mobility for location choice.

2) As far as preferences precede and affect residential location choice, within-household relationships have to be taken into account. Most RSS-travel studies focus on the individual level, as travel behavior is individual in nature (individuals make trips, even if people who share a household sometimes travel together, and even if there are household travel budgets) ${ }^{5}$. Preferences are typically measured either at the individual level for just one person in a household, or are measured by having a household member who is chosen as a representative give information on household preferences (see the data used by Chatman 2009; Bagley and Mokhtarian 2002; Schwanen and Mokhtarian 2005; Handy, Cao, and Mokhtarian 2005. The data used in the latter three papers account for the bulk of papers on RSS-travel overall). However, it is possible that preferences cannot be realized because of intra-household variation in preferences. There is considerable sociopsychological research on lifestyle and attitude alignment between partners in the course of partnership (Kalmijn 2005; Arránz Becker and Lois 2010), but contrasting preferences for housing and location are nonetheless likely to be at play. Household location choices are shaped by intrahousehold power relations based on gender, individual economic status, or other factors (Jarvis 2003; Blaauboer 2010).

In RSS-travel studies, a link has to be developed between household action and individual action. This can be done by opening the "black box" of the household ${ }^{6}$ and studying intra-household negotiations on and coordination of residential location choice, including possible convergence of preferences.

\footnotetext{
${ }^{5}$ Exceptions include Bhat and Guo (2007) and Cao, Mokhtarian, and Handy (2007), both studies of household car ownership levels, and Krizek (2003), which studies individual travel variables averaged at the household level.
} 
A more straightforward option would be to use mean values of household members' preferences. This, however, would not adequately reflect the differential power of various household members. Another valuable step forward would be to study the processes that shape residential location preferences (see below).

3) An implicit premise of RSS-travel studies is that most households find a residence that matches their preferences. Otherwise the correlations between preferences and travel behavior could not bias the effects of spatial context at the residence that have consistently been found in land-use travel studies that do not take RSS into account (Chatman 2009, 1027). This view is challenged by Naess (2005), who argues that the extent of self-selection in the city of Copenhagen is limited by the ability of households to choose freely on the housing market. The role of regional housing supply has been much less systematically studied in the RSS-travel field than individual/household characteristics and small-scale land use. Comparative studies on the RSS-travel link that take into account various urban regions with different housing market characteristics would be valuable .

4) There may be specific parts of the population, called self-selectors, who react to spatial context more than others (Chatman 2009, 1073). One may expect this to be true for households that seek spatial attributes that are particularly unequally distributed over space-e.g., captive PT users without a car in the household. For those who own a car, a residence close to a PT stop is not a problem as long as car access is warranted as well (and as long as the PT stop itself is not associated with other, possibly more disturbing, spatial attributes such as density, lack of parking space, etc.). Conversely, for those without a car a lack of PT service is likely to pose considerable problems. From these considerations, group-specific comparative approaches could offer valuable insight into the RSS-travel link.

Three conclusions may be drawn that make a mobility biographies perspective valuable. ${ }^{7}$

First, in travel studies it is standard to perceive residential location choice as a long-term decision that precedes daily access and travel behavior. The reverse role transport and access have in residential location choice suggests an intertwined "stream" of long-term and short-term decisions over an individual's life, which makes a biographical perspective worthwhile.

Second, within-household relationships plus, if possible, an individual's wider personal networks should be taken into account as relatively stable, long-term conditions that affect an individual's chances to realize his/her residential location preferences and, consequently, travel behavior. Again, this implies that a life-course-oriented, longitudinal perspective could shed light on the sequencing of events and changes.

Third, group-specific differences between self-selectors and other population groups defined by their resources or preferences may be traced over time to see how group memberships, resource availability, or preferences develop. People are not born with either strong or weak preferences, and self-selectors may attenuate their preferences when circumstances change or simply do not allow their realization. Again, this calls for a life-course perspective. Issues of preference are discussed in more detail in the next section.

\footnotetext{
${ }^{6}$ Studies on migration and residential choice are typically conducted at the household level. The household is then conceptualized as a unit of action and, hence, as a black box in which competing preferences held, actions undertaken by, and negotiations between individual members are ignored.
} 


\subsection{The role of preferences}

Preferences (see footnote 4 for a definition) are typically treated as impact factors of residential location choice and travel behavior in RSS-travel studies. Either they are modeled as exogeneous variables or as endogeneous to life situation (plus, possibly, lifestyles) but exogeneous to residential location and travel.

However, even in the 1970s evidence was found for mutual interdependencies between attitudes and (travel) behavior (Tardiff 1977), and this issue has remained a topic of inquiry ever since. Some more recent empirical findings lend no support to either direction of causality between car availability and location preferences being stronger than the other (Scheiner and Holz-Rau 2007). Another study suggests a strong effect of behavior on preferences. Bohte (2010,81-109) estimates SEMs for distances traveled and car share in trips in the Netherlands, including not only the effects of preferences on travel behavior, but also reverse effects. The study also finds that the effects of behavior on preferences is stronger than vice versa, and concludes that people adjust their preferences to their circumstances, as suggested by Festinger's (1957) cognitive dissonance theory. More generally, further confirmation of Bohte's finding by more studies would also suggest that adjustment to context and, hence, the effects of the built environment, have been underestimated by most recent RSS-travel studies.

The possibility that preferences are shaped by the (spatial) context someone lives in raises the wider question of the origin of preferences. Concerning the other source of RSS, people's socio-demographic attributes, it has always been relatively clear that these attributes are exogeneous to travel behavior (even if some reverse relationships are likely to exist-e.g., people may increase their income by accepting longer commute distances), and to other types of behavior likewise. This is particularly true for those sociodemographic variables whose origin is determined by nature (age, sex). However, preferences cannot simply be treated analogously. First, preferences should not be used as additive control variables beside socio-demographics in a single-equation framework, as their effects do not simply add on to the effects of life situation. Rather, they are endogeneous to life situation, because life situations typically impose certain preferences. Families may prefer a green, safe environment, while young single households may prefer a lively neighborhood with various urban amenities.

Second, the as-yet unclear mutual relationship between preferences and behavior, and between preferences and actual spatial context, calls for longitudinal studies that include measurements of preference change over time on the individual level. This suggests panel studies, as retrospective measures of preferences tend to be unreliable. These mutual interdependencies include the relationships between preferences and mobility tool ownership, between preferences and residential location choice, and between preferences and travel behavior. The association between lifestyles and preferences is another field that is as yet unclear from a theoretical perspective. Scheiner and Holz-Rau (2007) model neighborhood preferences as endogeneous to lifestyle. However, one may argue that neighborhood preferences are an integral part of lifestyles.

Another important aspect to consider with respect to the role of preference refers to the accuracy of measurement. Estimation of the relative effect magnitudes of different variables confronts the problem that all variables should be measured with approximately the same degree of accuracy. However, land-use variables are typically measured more precisely than preferences. Findings that the effects of preferences are weaker than those of land use should thus not lead to the conclusion that preferences play a minor role (Bohte, Maat, and van Wee 2009). For example, in German studies, attributes such as "access to the city centre" (StadtLeben) or "proximity to the city centre" (Intermobil Region Dresden ${ }^{8}$ ) have been used for importance ratings to capture residential location preferences. However, neither accessibility nor proximity is likely to be uniformly understood by respondents. Rather, one may suspect

${ }^{7}$ The original idea of the German StadtLeben project was to compare a supply-driven region where households have relatively little choice in residential location (Cologne) with a demand-driven region where preferences are supposed to play a stronger role (Leipzig). Unfortunately, the second case study could not be realized. 
that car owners have a larger "subjective proximity" radius than those without a car, and that they think of accessibility by car while those without a car may think of PT connections.

The value of a biographical approach to travel with respect to the role of preferences has already been briefly touched upon at the end of the preceding section. Such a framework could be used to study:

- Emergence of (travel and neighborhood) preferences as elements in an individual's life course.

- Adaptation of preferences to context over time. This would open up a wide field of research. First, "context" may include social and socioeconomic as well as spatial context—e.g. the neighborhood, the housing market or, more generally, the residential options in a region. "Adaptation" could also take many forms, including intensification or attenuation of preferences, or the convergence of preferences in partnerships or even in cross-generational relationships (e.g., alignment with children's preferences).

- Possible "negative adaptation" to context—e.g., when an individual rejects parental or societal norms by developing individual preferences in the opposite direction.

- Possible mutual interdependencies between preferences and (1) mobility tool ownership, (2) residential location choice, (3) travel behavior, and (4) lifestyles. The relationship between lifestyle and preference also calls for a more thorough theoretical framework.

\subsection{Implications for spatial planning and transport planning}

Probably the ultimate question that drives RSS-travel studies is whether land-use and transport systems are relevant for people's behavior, even if behavior statistically depends on preferences toward, rather than the objective attributes of, neighborhoods and transport systems.

A brief answer to this question may be yes, they are relevant, simply because land-use and transport systems are objective elements in an individual's situation of action ${ }^{9}$, and residential (or any other) preferences cannot be relevant without the objective conditions that enable them to be realized. Naess (2009) underlines this notion by arguing that "the fact that people to some extent 'self-select' into areas matching their transport attitudes and car ownership is in itself a demonstration of the importance of urban structure to travel behavior" (ibid., 298). The reason is that the process of RSS is conditioned on variety of supply in the land/housing market. One may add that, likewise, the RSS-travel link is conditioned on the fact that land use facilitates or prevents certain types of travel behavior, as otherwise people would have no reason to select themselves into certain locations. Consequently, any travel behavior model that controls for car ownership, travel, and residential preferences would lead to "over-control" (Naess 2009), as the assumed causal relationships do not adequately reflect reality's causality structures.

I agree with Petter Naess's theoretical grounds, although I would not agree that such models necessarily impose over-control. The RSS-travel debate has considerably improved understanding of travel behavior. I would rather suggest that preferences, like spatial context and behavioral variables, should be integrated in a longitudinal, biographically oriented research framework, precisely in order to capture the expected complex mutual relationships.

From a policy perspective, the RSS-travel debate provokes a second answer to the question raised

\footnotetext{
${ }^{8}$ The original questionnaires of both the StadtLeben and Intermobil Region Dresden projects are available from the author upon request (in German). See footnote 1 in Scheiner and Holz-Rau (2007) for brief information on both projects.

${ }^{9}$ The action-theoretical premises for this term are not discussed here. The debate on action versus behavior in spatial studies appears, at least to some extent, to be a continental European affair, with a focus on Germany (Werlen 1993). Action-theoretical approaches to travel also seem to be more pertinent in Europe than in the US (e.g. Lanzendorf 2001; Scheiner 2005; Naess 2013), while in the US the general perspective appears to be more behavioral-empirically oriented. While this may not always impose much difference in empirical modeling, it affects the interpretation of findings, as the focus in action theory is more on individuals' rationales (Naess 2013) and motives (Scheiner 2005) - i.e., on the subjective meaning of action, rather than on statistical associations between observable behaviour and its assumed causes. Hence, a discussion on the potentials and shortcomings of behavioral theory versus action theory (plus practice theory) could be of great value for the RSS-travel debate.
} 
above. Given the considerable individual freedom of choice in today's Western societies, spatial planning should address preferences and attempt to impact them in the desired direction (e.g., by informing people about behavioral consequences), rather than limiting its scope to the provision of housing, politically desired land-use structures, and transport systems.

Still, there is a need to provide such desired contexts, as the high land values in dense, mixed-landuse neighborhoods with well-established PT systems strongly support the idea that many people do indeed have preferences for such neighborhoods (i.e., those favored by most planners) (see LBS 2009 for Hamburg). The remarkable reurbanization trend that has emerged over the past decade (Herfert and Osterhage 2012; see also other chapters in the same book) has even amplified land price differences between cities and more peripheral areas.

These trends lend credit to the concern that some potential self-selectors who seek the type of residences that are desirable from a sustainability perspective do not find such residences, particularly in cities with an undersupply of urban housing (in Germany: Munich, Frankfurt/Main, Stuttgart, Hamburg, Berlin, Dusseldorf, Cologne, and others) (BBSR 2012). In this situation urban development policy may have great potential to achieve more sustainability (Chatman 2009, p. 1074). In the contrasting case of relatively unlimited potential for self-selection into all types of locations-i.e., households find the residential location they seek - there would be no mismatched households (see Schwanen and Mokharian 2005; Van Acker, Derudder, and Witlox 2011), and the development of politically desired urban structures would be unsuccessful. In such a case, strong associations between preferences and travel behavior in all types of locations are to be expected. Political approaches intended to guide spatial development in the desired direction could then include attempts either to influence preferences or to restrict freedom of choice (financially or legally).

For future urban research, these considerations suggest studying whether and how urban neighborhoods can be realized as new developments in a way that is convincing for households seeking historically evolved, lively settings with many amenities. Another valuable strand of research would be on the modification of preferences, drawing on related socio-psychological studies. As it is naturally related to trends over time, it should include longitudinal observations of preferences as well as associations with and changes in their potential impact factors, such as the influence of other household members and wider social networks and objective spatial context at the residence. This again points towards a biographical approach.

\footnotetext{
${ }_{10}$ Between the years 2003/2004 and 2008/09, the property and land prices in Germany increased by 17 percent in cities with more than 500,000 inhabitants, but decreased by 4 percent in their suburban hinterlands (author's calculations based on BBR 2003 and BBSR 2011).
} 


\section{Mobility biographies as a perspective for framing the RSS-travel link}

It has been shown above that RSS-travel studies could well be integrated into a wider perspective of mobility biographies (see Scheiner 2003 for an early call on this). The mobility biographies approach is an open concept for research that focuses on stability and changes in travel behavior over an individual's life course (Lanzendorf 2003). It includes a entire range of research questions and highlights changes in traveling induced by "transitions" such as key events (van der Waerden, Timmermans, and Borgers 2003), experiences, and learning processes. In this context, the key event of residential relocation plays an important role (Scheiner and Holz-Rau 2013).

Similarly, RSS-travel studies treat spatial mobility as a process of interrelated mobility decisions by which people navigate their life paths. They are based on the idea that travel behavior is embedded in the long-term aspirations and decisions of individuals or households on how and where to live, and how and where to move in daily life. Consequently, a noticeable share of RSS-travel studies is based on panel or quasi-panel analysis of before-and-after relocation travel behavior similar to mobility biographies studies (Scheiner and Holz-Rau 2013).

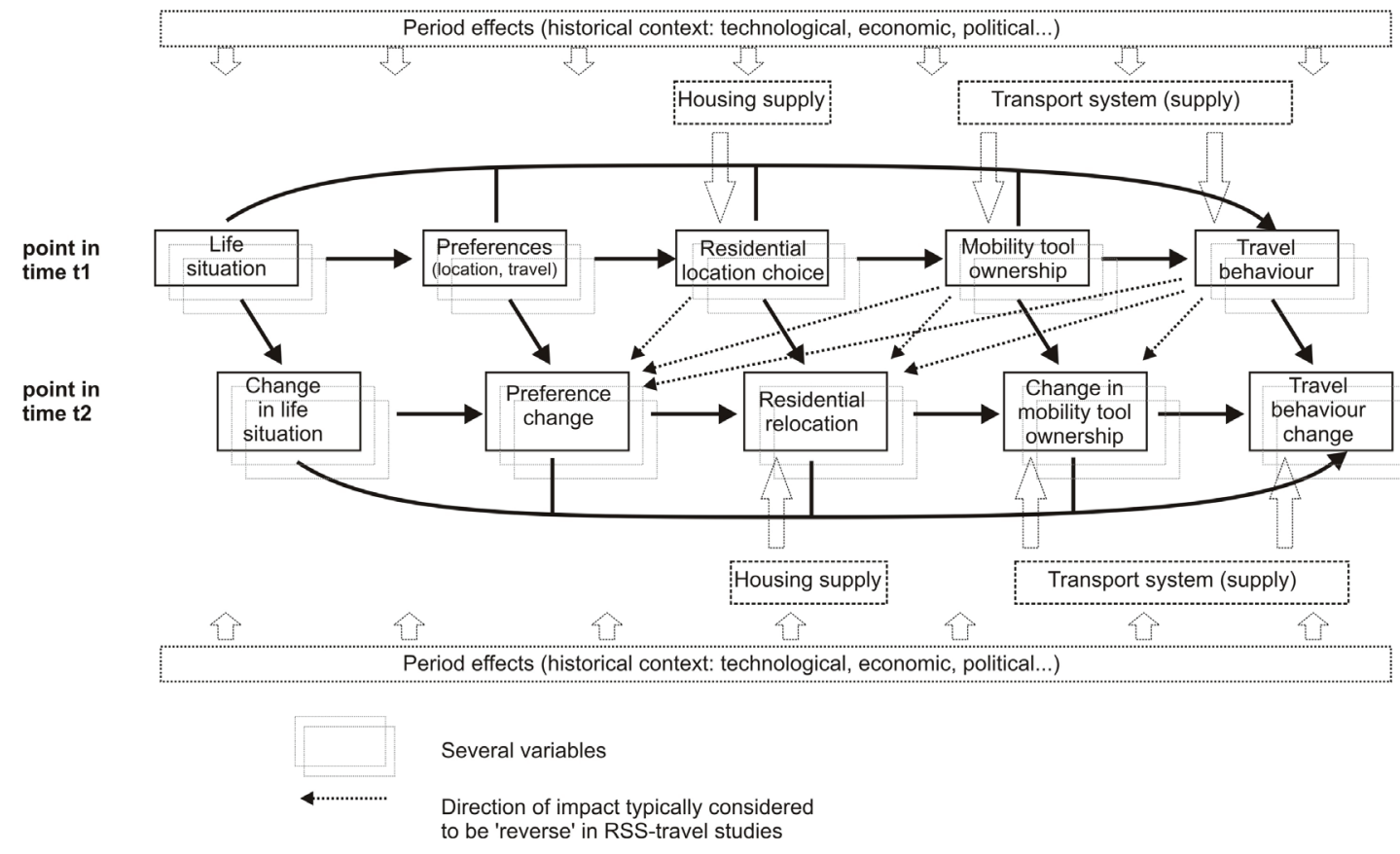

Figure 1: Process model of spatial mobility.

The difference between the two approaches is that the RSS-travel debate focuses on residential choice and travel, while the mobility biographies approach is much wider in scope, acknowledging that the mutually related decisions on residential choice and daily travel are themselves embedded in stability and change in the spatio-temporal and social context in which an individual lives (Figure 1).

The fruitfulness of understanding the RSS-travel link as embedded in mobility biographies lies in the openness of the latter approach towards other related "spheres" of individual life courses. The mobility biographies approach gives consideration not only to residential location choice and relocation, but to employment biographies that include workplace locations, household and family biographies, personal networks, and lifestyles. In this way it provides a more holistic framework for understanding mutually dependent interrelations between traveling and other spheres of an individual's life. Hence, the approach is also suitable to study interactions between various key events and other transitions that should not be 
understood separately. For instance, residential relocation is typically related to household or socioeconomic changes such as the birth of a child, a change in household income, or a change in workplace.

The embedding into mobility biographies could also serve to bring other forms of self-selection together with RSS in a joint framework. The choice of other locations such as workplaces, non-work trip destinations, secondary residences, or regular holiday destinations is also likely to be shaped by self-selection (Van Wee 2009; for Germany see Holz-Rau 1997, pp. 38-39). Self-selection of destinations may be based on the attractiveness of competing destinations, accessibility tolerance levels (Clark, Huang, and Withers 2003) or subjective values of travel time, depending on mode (Fosgerau, Hjorth, and Lyk-Jensen 2010). Mode choice and associated ownership are themselves likely to be subject to selfselection (Van Wee 2009).

Figure 1 serves as a starting point for a framework for the empirical study of key links. The assumed cause-impact chain at a certain point in time ( $\mathrm{t} 1$ ) may include a number of reverse causality effects that lead to changes in preferences, to residential relocation, or to purchase or disposal of mobility tools at a later point in time (t2). These interrelations are embedded in regional housing supply (which particularly affects choice of residence) and transport supply (which particularly affects mobility tool ownership and travel behavior).

Potentially, this framework can be extended to various points in time, which would open up the chance to study cohort effects and period effects, i.e., effects of historical changes in overall technological, economic, political, or socio-cultural context. A series of repeat measurements could also shed light on the sequencing and speed of adaptations in preferences and behavior. RSS-travel studies deal with enormous lags between location choice and travel choices. Hence, location choice may be based on completely different circumstances and preferences than those affecting travel choices.

It also must be noted that reverse causality issues may be much wider than indicated in the figure. The question as to which cause-impact directions are more pertinent than others is not just an empirical question but also deserves thorough theoretical discussion. Last but not least, location choice in the figure refers to the residence. This could be complemented by destination choice-e.g., with respect to workplace location. In this case the supply side would reflect the spatial distribution of workplaces in a region. However, housing supply would still play a role as it may affect the decision of whether to move closer to a new workplace.

\section{Conclusions}

This paper has made a case for integrating the RSS-travel link into the wider scope of mobility biographies. The mobility biographies approach is a rather broad, open research concept that focuses on stability and changes in travel behavior over an individual's life course. The thoughts raised represent a call for, rather than a detailed outline of, such a framing of the RSS-travel link.

RSS-travel research treats spatial mobility as a process of interrelated mobility decisions by which people navigate their life paths. It is based on the idea that travel behavior is embedded in people's longterm aspirations and decisions on how and where to live and how and where to move in daily life. A biographical approach could serve to frame these interrelated mobility decisions in the context of other spheres of life, most notably employment, the household and family, wider personal networks, and lifestyles. If extended to various points in time over longer periods, the sequencing and speed of adaptions in preferences and behavior could be studied as well as the role of historical changes in technological, economic, political, or socio-cultural context. This approach could contribute to a more accurate understanding of cause-impact relationships-e.g., between objective spatial context and subjective preferences toward such contexts. Overall, such a framing could be another step forward toward a more comprehensive understanding of spatial mobility. 


\section{References}

Aditjandra, P. T., C. A. Mulley, and J. D. Nelson. 2009. Neighbourhood design impact on travel behaviour: A comparison of US and UK experience. Projections: MIT Journal of Planning 9: Sustainable Transportation: An International Perspective. url: http://eprint.ncl.ac.uk.

Aditjandra, P. T., X. Cao, and C. Mulley. 2012. Understanding neighbourhood design impact on travel behaviour: An application of structural equations model to a British metropolitan data. Transportation Research Part A 46(1): 22-32. doi: 10.1016/j.tra.2011.09.001.

Aditjandra, P. T., C. A. Mulley and J. D. Nelson. 2013. The influence of neighbourhood design on travel behaviour: Empirical evidence from North East England. Transport Policy 26: 54-65. doi: 10.1016/j.tranpol.2012.05.011.

Arránz Becker, O., and D. Lois. 2010. Selection, alignment, and their interplay: Origins of lifestyle homogamy in couple relationships. Journal of Marriage and Family 72(5): 1234-1248. doi: 10.1111/j.1741-3737.2010.00761.x.

Bagley, M. N., and P. L. Mokhtarian. (2002): The impact of residential neighborhood type on travel behavior: A structural equations modeling approach. Annals of Regional Science 36(2): 279-297. doi: $10.1007 / \mathrm{s} 001680200083$.

Bauer, U., C. Holz-Rau and J. Scheiner. 2005. Standortpräferenzen, intraregionale Wanderungen und Verkehrsverhalten. Ergebnisse einer Haushaltsbefragung in der Region Dresden. Raumforschung und Raumordnung 63(4): 266-278. doi: 10.1007/BF03183813.

Bundesamt für Bauwesen und Raumordnung (BBR). 2003. INKAR 2003. Bonn: BBR.

Bundesinstitut für Bau-, Stadt- und Raumforschung im Bundesamt für Bauwesen und Raumordnung (BBSR). 2011. INKAR 2011. Bonn: BBSR.

Bundesinstitut für Bau-, Stadt- und Raumforschung im Bundesamt für Bauwesen und Raumordnung (BBSR) 2012. Wohnungs- und Immobilienmärkte in Deutschland 2011. Bonn: BBSR.

Beckmann, K. J., M. Hesse, C. Holz-Rau, and M. Hunecke (eds.). 2006. StadtLeben-Wohnen, Mobilität und Lebensstil. Neue Perspektiven für Raum- und Verkehrsentwicklung. Wiesbaden: VS Verlag.

Bhat, C. R., and J. Y. Guo. 2007. A comprehensive analysis of built environment characteristics on household residential choice and auto ownership levels. Transportation Research Part B 41(5): 506526. doi: 10.1016/j.trb.2005.12.005.

Blaauboer, M. 2010. Family background and residential choice. PhD thesis, University of Amsterdam, Faculty of Social and Behavioural Sciences. dare.uva.nl/document/192750.

Bohte, W. 2010. Residential self-selection and travel. The relationship between travel-related attitudes, built environment characteristics and travel behaviour. PhD thesis, TU Delft, Delft Centre for Sustainable Urban Areas. repository.tudelft.nl/assets/uuid:98180624-4036.../OTB_SUA035_web.pdf.

Bohte, W., K. Maat, and B. van Wee. 2009. Measuring attitudes in research on residential self-selection and travel behaviour: A review of theories and empirical research. Transport Reviews 29(3): 325-357. doi: 10.1080/01441640902808441.

Cao, X., P. L. Mokhtarian, and S. L. Handy. 2007. Cross-sectional and quasi-panel explorations of the connection between the built environment and auto ownership. Environment and Planning A 39(4): 830-847. doi: 10.1068/a37437. 
Cao, X., P. L. Mokhtarian, and S. L. Handy. 2009. Examining the impacts of residential self-selection on travel behaviour: A focus on empirical findings. Transport Reviews 29(3): 359-395. doi: $10.1080 / 01441640802539195$.

Carlstein, T., D. Parkes, and N. Thrift (eds.) 1978. Timing Space and Spacing Time. Vol. 1: Making Sense of Time. Vol. 2: Human Activity and Time Geography. Vol. 3: Time and Regional Dynamics. London: Edward Arnold.

Chatman, D. G. 2009. Residential choice, the built environment, and nonwork travel: Evidence using new data and methods. Environment and Planning A 41(5): 1072-1089. doi: 10.1068/a4114.

Clark, W. A.,V. Y. Huang, and S. Withers. 2003. Does commuting distance matter? Commuting tolerance and residential change. Regional Science and Urban Economics 33: 199-221. doi: 10.1016/ S0166-0462(02)00012-1.

Dieleman, F. M., and C. H. Mulder. 2002. The geography of residential choice. In J. I. Aragonés, G. Francescato, and T. Gärling (eds.). Residential Environments: Choice, Satisfaction, and Behavior, 35-54. Westport, CT/ London: Bergin \& Garvey.

Festinger, L. 1957. A Theory of Cognitive Dissonance. Stanford, CA: Stanford University Press.

Fosgerau, M., K. Hjorth, and S. V. Lyk-Jensen. 2010. Between-mode-differences in the value of travel time: Self-selection or strategic behaviour? Transportation Research Part D 15(7): 370-381. doi: 10.1016/j.trd.2010.04.005.

Frick, J. 1996. Lebenslagen im Wandel: Determinanten kleinräumlicher Mobilität in Westdeutschland. Frankfurt/Main, New York: Campus.

Götz, K., T. Jahn, and I. Schultz. 1997. Mobilitätsstile: ein sozial-ökologischer Untersuchungsansatz. Forschungsbericht Stadtverträgliche Mobilität 7. Frankfurt am Main: Institut für sozial-ökologische Forschung.

Grund, E. 1997. Die Stadt der kurzen Wege-eine Illusion. Straßenverkehrstechnik 41(2): 57-61.

Handy, S., X. Cao, and P. Mokhtarian. 2005. Correlation or causality between the built environment and travel behavior? Evidence from Northern California. Transportation Research Part D 10(6): 427444. DOI 10.1016/j.trd.2005.05.002.

Herfert, G., and F. Osterhage. 2012. Wohnen in der Stadt: Gibt es eine Trendwende zur Reurbanisierung? Ein quantitativ-analytischer Ansatz. In K. Brake and G. Herfert (eds.). Reurbanisierung. Materialität und Diskurs in Deutschland, 86-112. Wiesbaden: VS Verlag.

Herkner, W. 1991. Lehrbuch Sozialpsychologie. 5th edition. Bern: Hans Huber.

Hesse, M., and J. Scheiner. 2009. Residential location, mobility and the city: Mediating and reproducing social Inequity. In T. Ohnmacht, H. Maksim, and M. Bergman (eds.). Mobilities and Inequality, 187-206. Aldershot: Ashgate.

Holz-Rau, C. 1997. Siedlungsstrukturen und Verkehr. Materialien zur Raumentwicklung 84. Bonn: Bundesforschungsanstalt für Landeskunde und Raumordnung.

Holz-Rau, C., P. Rau, J. Scheiner, K. Trubbach, C. Dörkes, A. Fromberg, P. Gwiasda, and S. Krüger. 1999. Nutzungsmischung und Stadt der kurzen Wege: Werden die Vorzüge einer baulichen Mischung im Alltag genutzt? Werkstatt Praxis 7/1999 des Bundesamtes für Bauwesen und Raumordnung. Bonn: BBR.

Horowitz, J. 1986. Modeling choices of residential location and mode of travel to work. In S. Hanson (ed.). The Geography of Urban Transportation, 207-226. New York: The Guilford Press.

Jarvis, H. 2003. Dispelling the myth that preference makes practice in residential location and transport behaviour. Housing Studies 18(4): 587-606. doi: 10.1080/02673030304247.

Jones, P. M., M. C. Dix, M. I. Clarke, and I. G. Heggie. 1983. Understanding Travel Behaviour. Aldershot: Gower. 
Kalmijn, M. 2005. Attitude alignment in marriage and cohabitation: The case of sex-role attitudes. Personal Relationships 12(4): 521-535. doi: 10.1111/j.1475-6811.2005.00129.x.

Kalter, F. 1997. Wohnortwechsel in Deutschland. Ein Beitrag zur Migrationstheorie und zur empirischen Anwendung von Rational-Choice-Modellen. Opladen: Leske+Budrich.

Kitamura, R., P. L. Mokhtarian, and L. Laidet. 1997. A micro-analysis of land use and travel in five neighborhoods in the San Francisco Bay area. Transportation 24(2): 125-158. doi: 10.1023/A:1017959825565.

Krizek, K. J. 2003. Residential relocation and changes in urban travel. Does neighborhoodscale urban form matter? Journal of the American Planning Association 69(3): 265-281. doi: 10.1080/01944360308978019.

Lanzendorf, M. 2001. Freizeitmobilität. Unterwegs in Sachen sozial-ökologischer Mobilitätsforschung. Materialien zur Fremdenverkehrsgeographie 56. Trier: Universität.

Lanzendorf, M. 2003. Mobility biographies: A new perspective for understanding travel behaviour. Paper presented at the 10th International Conference on Travel Behaviour Research (IATBR), Lucerne, August 10-15, 2003. www.ivt.ethz.ch/news/archive/.../lanzendorf.pdf.

LBS Bausparkasse Schleswig-Holstein-Hamburg AG (LBS). 2009. LBS-Immobilienmarktatlas 2009 Hamburg und Umgebung. Hamburg: LBS. www.lbs.de/shh/lbs/pics/upload/tfmedia1/ HBSAAddayzf.pdf

Mas-Colell, A., M. Whinston, and J. Green. 1995. Microeconomic Theory. Oxford: Oxford University Press.

Mokhtarian, P. L., and X. Cao. 2008. Examining the impacts of residential self-selection on travel behavior: A focus on methodologies. Transportation Research Part B 42(3): 204-228. doi: 10.1016/j. trb.2007.07.006.

Naess, P. 2005. Residential location affects travel behavior-but how and why? The case of Copenhagen Metropolitan Area. Progress in Planning 63(2): 167-257. doi: 10.1016/j.progress.2004.07.004.

Naess, P. 2006. Accessibility, activity participation and location of activities: Exploring the links between residential location and travel behaviour. Urban Studies 43(3): 627-652. doi: $10.1080 / 00420980500534677$.

Naess, P. 2009. Residential self-selection and appropriate control variables in land use: Travel studies. Transport Reviews 29(3): 293-324. doi: 10.1080/01441640802710812.

Naess, P. 2013. Residential location, transport rationales and daily-life travel behaviour: The case of Hangzhou Metropolitan Area, China. Progress in Planning 79: 1-50. doi: 10.1016/j.progress.2012.05.001.

Ohnmacht, T., K. Götz, and H. Schad. 2009. Leisure mobility styles in Swiss conurbations: Construction and empirical analysis. Transportation 36(2): 243-265. doi: 10.1007/s11116-009-9198-8.

Park, R. E., R. D. McKenzie, and E. Burgess. 1925. The City. Chicago: University of Chicago Press.

Pickup, L., and S. W. Town. 1983. Commuting Patterns in Europe: An Overview of the Literature. Transport and Road Research Laboratory (TRRL) supplementary report 796. Crowthorne, Berkshire: TRRL.

Scheiner, J. 1998. Aktionsraumforschung auf phänomenologischer und handlungstheoretischer Grundlage. Geographische Zeitschrift 86(1): 50-66.

Scheiner, J. 2000. Eine Stadt-zwei Alltagswelten? Ein Beitrag zur Aktionsraumforschung und Wahrnehmungsgeographie im vereinten Berlin. Abhandlungen Anthropogeographie 62. Berlin: Dietrich Reimer. 
Scheiner, J. 2003. Housing mobility and travel behaviour: a process-oriented approach to spatial mobility. Evidence from a new research field in Germany. Paper presented at the RGS-IBG International Annual Conference: Geography, Serving Society and the Environment, September 3-5, 2003, London.

Scheiner, J. 2005. Daily mobility in Berlin: On "inner unity" and the explanation of travel behaviour. European Journal of Transport and Infrastructure Research 5(3): 159-186. http://www.ejtir.tbm. tudelft.nl/issues/2005_03/pdf/2005_03_02.pdf.

Scheiner, J. 2009. Sozialer Wandel, Raum und Mobilität. Empirische Untersuchungen zur Subjektivierung der Verkehrsnachfrage. Wiesbaden: VS Verlag.

Scheiner, J. 2010. Social inequalities in travel behaviour: trip distances in the context of residential self-selection and lifestyles. Journal of Transport Geography 18(6): 679-690. doi: 10.1016/j.jtrangeo.2009.09.002.

Scheiner, J., and C. Holz-Rau. 2007. Travel mode choice: Affected by objective or subjective determinants? Transportation 34(4): 487-511. doi: 10.1007/s11116-007-9112-1.

Scheiner, J., and C. Holz-Rau. 2013. Changes in travel mode choice after residential relocation: A contribution to mobility biographies. Transportation 40(2): 431-458. doi: 10.1007/s11116-0129417-6.

Schwanen, T., and P. L. Mokhtarian. 2005. What if you live in the wrong neighborhood? The impact of residential neighborhood type dissonance on distance travelled. Transportation Research Part D 10(2): 127-151. doi: 10.1016/j.trd.2004.11.002.

Tardiff, T. J. 1977. Causal inferences involving transportation attitudes and behavior. Transportation Research 11(6): 397-404. doi: 10.1016/0041-1647(77)90004-1.

Van Acker, V., B. Derudder, and F. Witlox. 2011. Spatial mismatch and its travel consequences. Paper presented at the mobil.TUM workshop, Making Sustainable Mobilities-Interdisciplinary Perspectives, April 7-8, 2011, Munich.

Van Acker, V., and F. Witlox. 2010. Car ownership as a mediating variable in car travel behaviour research using a structural equation modelling approach to identify its dual relationship. Journal of Transport Geography 18(1): 65-74. doi: 10.1016/j.jtrangeo.2009.05.006.

Van der Waerden, P. H. Timmermans, and A. Borgers. 2003. The influence of key events and critical incidents on transport mode choice switching behaviour: A descriptive analysis. Paper presented at the 10th International Conference on Travel Behaviour Research (IATBR), August 10-15, 2003, Lucerne.

van Wee, B. 2009. Self-selection: A key to a better understanding of location choices, travel behaviour and transport externalities? Transport Reviews 29(3): 279-292. doi: 10.1080/01441640902752961.

van Wee, B., H. Holwerda, and R. Van Baren. 2002. Preferences for modes, residential location and travel behaviour: the relevance for land-use impacts on mobility. European Journal of Transport and Infrastructure Research 2(3-4): 305-316. http://www.ejtir.tbm.tudelft.nl/issues/2002_03-04/ pdf/2002_03-04_08.pdf

Vance, C., and R. Hedel. 2007. The impact of urban form on automobile travel: disentangling causation from correlation. Transportation 34(5): 575-588. doi: 10.1007/s11116-007-9128-6.

Werlen, B. 1993. Society, Action and Space. An Alternative Human Geography. London: Routledge. 